\title{
Specifics of Institutional Competitivenes Formation in the Conditions of Innovation Development
}

\author{
Elena Blagireva \\ Russian State Specialized Arts Academy \\ Moscow, Russia \\ E-mail: blagireva@ list.ru
}

\begin{abstract}
Competitive advantages of the national economy may strengthen its position and promote innovational development, institutional limitations, and negative factors effecting its future development. The negative factors should be eliminated or weakened. At the same time any negative factors and limitations of its results in certain conditions may be seen as advantages, i.e. may be used as institutional stimulae in the development of certain industrial complexes as well as attraction of investment resources into particular economic spheres. Production and services quality improvement regulated at every power level should become a serious factor of competitiveness increase of the Russian goods and services, which leads to production volume growth and GDP growth.
\end{abstract}

Keywords-competitiveness; institutional stimulae; economics; innovation development; production quality; production volume

\section{INTRODUCTION}

Let us remember the term institutionalism translated from Latin means a custom, a teaching, a rule. Institutionalism representatives believe in the moving power of the social development those institutes, which primarily match political, economic, cultural, ideological and other structures of the society. Except for the institutes, the main power of the social development are the scientists, who belong to this movement, who justify the social psychology of the people, its character, temperament and even instincts. Other national features of institutionalism are: negation of the ability of the capitalist world to selfregulation, marginalize main principles critics, etc. These productive and deep approaches have gained greater popularity in modern Russia.

\section{SPECIFICS OF FORMATION OF INSTITUTIONAL COMPETITIVENESS IN RUSSIA}

In recent years Russia has experienced active formation of institutional competitiveness. Let us overview the general specifics of this process. So, in the Far East there have been created nine advanced development territories: in the Sakha Yakoutia Republic, in Primorie, Khabarovsk areas, Amur area, in Tchoukotka and Kamchatka. It is planned to organize such spaces in the Russian and the Great Ussourian islands as well as the other areas of the Far East. Even wider preferences will go to the residents of the free port
Vladivostok. In October of this year a law will be passed which will cover the key ports of South of Primorie - from Zarubino port to Nakhodka as well as 15 municipal areas, where about $75 \%$ of the Primorie area are currently living.

As President V.V. Putin has marked on the First Eastern Economic Forum, in recent years the Far East region has had several dozen of its major projects have started. Many of them have a national or even global scale. It is the start of the oil tube "Eastern Siberia - the Pacific Ocean"; Vladivostok Federal University inauguration, Siberian Power gas pipe construction, the ending of the space launch construction Vostochny, Baikal-Amur railroad modernization, Trans-Siberian railroad modernization, Sakhalin, Magadan, Kamchatka oil shelves development, the Eastern Oil and Chemical Complex development, a modern cluster of shipbuilding and the marine technics development, iron ore, gold and other mineral resources industry development, and successful agrarian projects.

In modern conditions of the market economy the notions of quality and competitiveness have become practically synonymous. That is why the main priorities in the Far East are an active policy of social development, the formation of the modern transport and educational infrastructures, available accommodation construction, creation of a new system of medical services and the development of economic liberty. Also, offering to Russian and foreign investors the best conditions for business and efficiency increase and healthy competitiveness with the leading business centers. The state on its turn should offer special financial conditions for the development of competitive enterprises. For instance, if an investor offers his resources to the Far East into the oil or gas fields, then the state is ready to help with the creation of a necessary infrastructure, which will allow to decrease the spending and to cut the time of cost and provide for the efficiency of the project.

According to the experts, it is also a very important investment. For instance, the state is ready to invest in the first six projects from the budget as this will allow the attraction of private investments of 126.5 bln. Rub. The ratio is one to nine. This instrument will be actively used, which means, the number of projects will be growing.

Co-financing of the projects will also considered. It will be held from the resource of the Foundation of the 
Development of the Far East and the Russian Foundation of the Direct Investments A decision has been made to direct the means for the construction of the bridge Nizhneleninskoye - Tundzian, which will unite Russia to China. We should note that RFPI together with the Russian and foreign partners has already invested over 50 bln Rub into the Far East projects. As for FRDV, it will allow resources on the long-term beneficial conditions of lower interest rates. This coming from the Letter of the President to the Federal Council a mechanism of extra-capitalization of the foundation.

According to V.V. Putin, other measures for the support of the projects are considered. Thus, the state frontier procedures for business are considerably facilitated. The ports will be working 24 hours a day. Electronic cargo declaration is also considered. An 8-day visa is offered right on the frontier. The residents will be offered different benefits.

It is typical that the Far East economy and in particular, the territories of the advanced development will be built considering competitiveness in the Eurasian economic Union, which is offering a complete regional market with free cargo and capital, and labor and services movement without extra restrictions. "It is a WTO principles market," stressed V.V. Putin. And this economic space is growing.

This year Russia has signed an agreement on the creation of the free trade zone between European-Asian Economic Union and Vietnam. Opportunities of similar agreements between Israel, India, and Egypt are considered. A project called the Economy Belt of the Silk Way is very well coordinated with EAEU. It makes all the processes easier, helps mutual investment and develops transport infrastructure. These economic structures complement each other and create new opportunities for the development of every participant. A new configuration of the trade ways is actually being formed in Europe and Asia. It will definitely influence the development of the continent as well as the world economy in general. Thus, the cargo from China will get to Europe with only two customs borders. There are now transport ways through Kazakhstan and European Russia actively being developed. At the same time there are already existing routes: the Trans-Siberian and the Baikal-Amur ones. It is planned that up to 500 bln Rub will be spent for Baikal-Amur and the Trans-Siberian railroads modernization up to 2017. The Northern sea route has a great competitive potential. There is a goal to make it a global corridor for container transportation, which dominate in the world cargo circulation. All these plans are aimed to the perspective economic development of the EAEU and Russia

As the concept of the long-term social-economic development of the Russian Federation up to 2020, the Russian Economy has faced long-term system challenges, reflecting the world tendencies as well as the internal development barriers. Among the first, there is a global competitiveness increase, covering not only traditional trade markets, capitals, technologies and labor, but also the system of the national management, innovation support, and human potential development. In this situation there is only one solution: to make an accent of the realized need to keep to the civilized behavior of the market, oriented to the constant competitiveness and product quality increase in accordance with the customer demand. At the same time there should be professional associations and different societies, based on different influence methods and spreading on all the stages of the goods life circle

It is expected that in the nearest decades the developed countries and Russia will pass to the formation of the new technological basis of economic system, based upon the usage of modern science and technology advances. In Russia there is great scientific and research potential in the field of high technology development, which, as the Concept says, creates the conditions for:

- the formation of the complex, of the highlytechnological industry, and the increasing of the position in the world market of the scientific product;

- increase of the Russian strategic presence in the highly technological production and intellectual services;

- modernization of traditional economic industries, including the globally oriented specialized industries.

At the same time the development of new technologies is lagging behind and may lower competitiveness of the Russian economy and also increase its vulnerability in the conditions of the growing geo-political competition. At the same time it should be considered that the competitive level of modern innovational economy is largely determined by the quantity of professional staff, their specialization level, and cooperation.

In the Russian and Belorussian regions forum, which took place in Sochi in September 2015, V.V. Putin has stressed that an unfriendly macroeconomic movement influences the Russian economy badly, but if the dollar equivalent is decreasing, then the Ruble one is growing. In general the trade currents have not decreased. The President expressed assuredness that the trade currents between Russian and Belorussia will be back to the previous growth track in every point. Investments should largely help this. The volume of the Russian capital in Belorussian economy is over 6 bln Rub - that is half of all the investments into the CIS countries. About 3.5 thousand joint ventures have been created.

Thus, Sverdlovsk regional enterprises take part in modernization of Grodno electric power station. Technics is completed in Penza region from the Belorussian parts. Cooperation in different spheres is being held from agriculture to space industry.

The Vice-Premier A. Dvorkovich declared that the Russian agriculture is planning to refuse GM products. This will lead to the fact that the Russian products will be the cleanest in the world. And logically will become one of the most competitive ones and will first of all replace foreign goods. Here it is very important to choose an economically friendly and effective strategy. 
According to V.V. Putin, foreign goods replacement is not a kind of fetish, but one of the most important double technologies. Foreign goods replacement is a one of highlytechnological industries. It should be done with double power and double effect.

For Russia it means overcoming of the existing negative tendencies, overcoming the development of human potential characterized by the reduction of population and the level of occupation in the economy, the growing competition with the European and Asian markets concerning qualified staff. The increase of the role of human capital is the main factor of economic development. At the same time the regress in the development of the new technologies of the latest generation may decrease the competitiveness of the Russian economy as well as increase its vulnerability in the conditions of the growing geopolitical competition.

If the Russian producer is aiming for higher goods and services quality, then the system solution of the objectives is the transition of the Russian economy from raw materials export to the innovational social-oriented development type.

Such an approach will allow to increase the potential of the Russian economy by means of the increase of its competitive advantages in science, education, high technologies and thus create new sources of economic growth and well-being.

Here we mean the formation of an innovational economy, which means that of the intellect; creative potential should become the leading factor of the economic growth and national competitiveness. The source of high income is not only the rent from the natural resources, but also the creation of new ideas, technologies and social innovation. This allows Russia to compete with the cheap labor force of China and India and with the highlyinnovative production of the developed countries of Europe, the USA and Asia By 2020 the new economy and the national GDP should reach the oil and gas and natural resource industries. The economical knowledge share and the high technologies industries should be no less than 17$20 \%$ of GDP (in comparison: only $10 \%$ in 2007). Internal research expenses and developments should rise up to 2.5$3 \%$ by 2020 (1.1\% in 2007). Certainly, the result of the fundamental research should also increase.

The specifics of the transition to innovational socialoriented type of economic growth is that Russia has to solve the problems of catching and advancing development. In the conditions of global competition and open economy it is impossible to reach the level of the developed countries on the benefits of efficiency without providing an advancement in development of those sectors of the Russian economy, which define its specialization in the modern economy.

At the same time it is important to consider that the transition from the export-material to the innovational model of economic growth is connected to the forming of the new mechanism of social development, based on the freedom of entrepreneurial freedom, social justice, and national competitiveness
An innovational type of economic growth demands increased beneficial conditions for the business initiative, competitiveness increase and investment attractiveness of the Russian private companies, their ability to work in the high competition conditions in global markets - since private companies are the major power of economic development. It is the state that can create conditions and stimulate business development, at the same time it should not substitute business with its own activity.

In order to transit to an innovational social-oriented state development in its relationship with the entrepreneurial subjects the state should consider the following:

- creation of conditions for entrepreneurial freedom and competitiveness, development of the mechanisms of self-regulation of business society;

- decrease of administrative barriers in economics;

- turning Russia into a low corruption level country;

- formation of conditions for mass private companies in every sphere of economics, coordinated with business;

- elimination of extreme state regulation and the transition to the non-direct methods of economic processes regulation;

- step by step reduction of the state participation in the property management in competitive industries by means of transparent and effective privatization procedures, based on the principles of market evaluation, equal property access and the availability of the state power bodies.

Together with the Concept and the Bases of the Policy of the Russian Federation in the area of science and technology development up to the year 2020 and its further perspective (stated by the President of the Russian Federation on 11.01.2012) and the Strategy of innovation development of Russian Federation up to the year 2020 (Government decree \#227-p from 08.12.2011), one of the basic elements of the system of the governing of economic and scientific development of the country is a long-term forecast of the scientific development of the Russian Federation. Its main objective is the development of variation of long-term scientific-technological development based on positions of the country in the system of international scientific and technological cooperation, as well as the necessary measures for the development of innovation system.

At the same time with the long-term forecast there are industrial strategies, federal and administrative objective programs, the strategies of the major state corporations, the programs for fundamental state corporations, programs for studies for the state academies, leading universities, national and state scientific centers, and strategic research programs. The major objectives of the state policy of Russian Federation are:

- increase of the efficiency of the state participation in the development of science and technology (first of 
all the Russian fundamental science as well as the applied research of the national security and life provision systems and other spheres of the state responsibility;

- creation of innovational attractiveness of the research segment in order to increase the share of non-state funding of the research and development sector of the Russian Federation and the decrease of the share of the state funding down to figures of the developed countries intellectual property;

- creation of the competitive innovational system and activation of the processes in the national economy and social sphere, including the development of the mechanisms of the state-private partnership in innovational sphere;

- providing of the rational integration of Russian science into the international system in the national interests of the Russian Federation.

Actual objectives in the framework of these priorities is realized within the state programs of the Russian Federation, in particular: "Development of science and technologies", "Educational Development", "Economic Development and Innovational Economy", "Industrial Development", "Information Society".

General innovational policy will be connected with the decision of the problems of innovational development in different sectors of the economy and social sphere.

At the same time the expenses on scientific, research, and experience, and construction works in Russia (USA $2.9 \%$ GDP, China - 1.8\%, Republic Korea - 3.74\%, Japan 3.4 GDP).

The leadership variant in the leading scientific-technical sectors and fundamental research is characterized by modernization of the Russian Science and Research sector and fundamental science, concentration of effort on the breakthrough of the scientific and technological directions, which allows to increase the application of the Russian development and to improve the Russian positions in the world market of the highly technological production and services, effectiveness increase of the Russian sector of knowledge and business generation and the development of the technological.

Potentially, Russia may demand the leading positions in aviation, Nano-technologies, composite materials, nuclear power and hydrogen energy, biomedical technologies, life provision and human and animal protection, ecology, etc. This variation is characterized by an increase of the demand to the new scientific and engineering staff as well as the formation of developed national innovation system, including innovational clusters on the regional level and reconstruction of the leading positions of the Russian national fundamental science.

By the year 2030 the structure of the science expenses will be cut on wages down to $30 \%$. The growth of the salaries in the innovation scenario will be accompanied by the increase of the effectiveness of the scientific and technical complex.

Stimulation of the research and development will be promoted also through "innovation motivation" of the large companies with the state share and the development of the innovational programs, which will become a stimulus to the competitiveness increase of the industries by the increase of the demand on goods and services. Major state companies expenses on the mentioned programs by 2015 will include 1.5 bln Rub, and by 2020 - 2 bln Rub.

At the same time the state companies will improve cooperative management systems of innovation management in order to overcome the gap between the leading foreign companies.

In order to increase competitiveness in Russia the state indicates the norms and frames of economic relationships, creates and establishes the legal, technical and organizational and informational infrastructure, makes work on licensing, structuration, certification, state control. First of all, this is aimed at the customer's protection against the poor quality product.

A world-wide recognized American specialist on quality management D. Harrington said that the product quality is the main battlefield in the world market... and the price of the loss in this battle is an economic disaster!

According to the Competition Law there is an objective process of the product quality increase in the world and the price reduction. In the conditions of competition nobody makes no one to increase the product quality, except for bankruptcy. As a result there is a constant process of the "washing out" of the poor quality goods and services from the market.

An important factor of competitiveness increase for Russia is the development of the interior market. Since the USSR times the Russian industry will be based upon the interior market. The interior market is the priority for the Russian industry. This is particularly obvious in this difficult time when Russia has the yoke of the sanctions.

In July 2015 at the State Security Council sitting V.V. Putin marked the necessity to develop the new offers on the bases of strategic planning and the forecast of the constant social economic growth of Russia and risk management. Marking that the limitation measures not only have become limitations, but also offered new opportunities for Russia. "First of all, our producers may considerably strengthen their positions in the interior market. We will continue the support of the projects, connected to the foreign goods substitutions in agriculture, defense and production complex, machinery, pharmaceutical and chemical industries. If necessary, these enterprises will get an extra support." - said the Head of the State.

Goods Competitiveness Demands Innovational and Entrepreneurial Approach and still one of the major moving powers on competitiveness is the process of innovations stimulation. Based on them, goods quality may be increased and a competitive advantage may be gained. Therefore, 
goods competitiveness demands innovational approach, breakthrough technologies. This position was confirmed by the Business Russia forum in May 2015, where Vladimir Putin called for the creation of Russia's new canters on technics and technology development.

In the author`s opinion, competitive advantages of the national economy may increase its position and help its innovational development, while the institutional restrictions limit its development. An influence of such negative factors should be either eliminated or considerably weakened. At the same time, any negative factors and limitations may be turned into advantages, i.e. to be used as institutional stimulate of particular complexes and attract investment resources into particular spheres of the economy.

\section{CONCLUSION}

Product and services quality increase at the norms and legal regulation, provided all levels may become a serious factor of competitiveness increase of Russian goods and services, which in its turn should lead to the increase of the production level and to GDP growth.

\section{REFERENCES}

[1] Agapova I.I. (2010) History of economic thought.

[2] Burko R.A. (2013) Causes of production in Russia production of poor quality and its low competitiveness. Young scientist, no. 11, pp. 298299.

[3] The civil code of the Russian Federation (2013), p. 736.

[4] Kane M.M., Ivanov B.V., Koreshkov V. N. and other (2012). Systems, methods, and tools of quality management: textbook for universities, p. 576.

[5] The code of the Russian Federation About administrative offences (KoAP of the Russian Federation) from 30.12.2001 N 195-FZ (as amended from 08.06.2015).

[6] Lukanin Yu.V. (2012) Structural aspects of the institutional competitiveness of the national economy. Terra ECONOMICUS. T. 10, vol. 3, pp. 5-8.

[7] Mazur I.I. (2011) Quality Management, p. 399.

[8] About consumer protection: the Federal law from 07.02.1992 N 2000-1-FZ (as amended on 01.07.2014).

[9] On ensuring the uniformity of measurements: the Federal law dated 26.06.2008 N 102-FZ (as amended on 21.07.2014).

[10] On technical regulation: the Federal law of 27.12.2002 N 184-FZ (as amended 22.12.2014). 